Lena Rodrigues Soares ${ }^{1}$

Wilza Vieira Villela ${ }^{2}$

\section{O assédio moral na perspectiva de bancários}

\author{
Bank workers' perspectives on bullying
}

1 Psicóloga. Mestre em Saúde Coletiva pela Universidade Federal de São Paulo. São Paulo, SP, Brasil.

2 Médica Livre Docente. Docente do Programa de Pós-Graduação em Saúde Coletiva da Universidade Federal de São Paulo, São Paulo, SP, Brasil.

Trabalho baseado na dissertação de mestrado Assédio moral na perspectiva dos bancários de autoria de Lena Rodrigues Soares, sob orientação de Wilza Vieira Villela, defendida em dezembro de 2011 no Programa de Pós-graduação em Saúde Coletiva da Universidade Federal de São Paulo.

O trabalho não foi subvencionado e não apresenta conflitos de interesse. Foi parcialmente apresentado na modalidade "apresentação oral" na Conferência Internacional sobre Assédio Moral e outras Manifestações de Violência no Trabalho: Ética e Dignidade dos Trabalhadores, realizada no Rio de Janeiro, em 2010.

Contato:

Lena Rodrigues Soares

Email:

lena-soares@uol.com.br

\section{Resumo}

Este artigo discute o assédio moral nas instituições bancárias, tomando por base uma discussão conceitual do tema e um estudo empírico desenvolvido com funcionários de um banco da região Norte do Brasil. Tendo em vista uma delimitação teórico-conceitual, apresenta, com base em estudiosos consagrados na literatura, breve histórico da discussão sobre o fenômeno, bem como definições e características que o distinguem de outros conflitos recorrentes em ambientes de trabalho. Discute também o papel das organizações de trabalho quanto ao assédio. Apresenta ainda resultados de pesquisa realizada em agências bancárias durante os meses de julho, agosto e setembro de 2010 por meio de entrevistas individuais semiestruturadas, aplicadas a 37 voluntários que exerciam diferentes cargos nessas agências. Foi possível identificar que o assédio moral, como forma de violência, é um fenômeno reconhecido pelos bancários em seu ambiente de trabalho e que, em geral, os sujeitos associam o assédio moral à forma de gestão por pressão, focada em metas, produção e competitividade. Os resultados também incitam a reflexão de que é necessário tratar o assédio moral em uma perspectiva coletiva, como uma questão social, e não individual.

Palavras-chave: violência no trabalho; assédio moral; saúde do trabalho; instituições bancárias.

\begin{abstract}
This paper discusses bullying in banks. It is based on a conceptual discussion of the topic and on an empirical study conducted with employees of a bank from the Northern region of Brazil. Based on a theoretical and conceptual delineation and on the work of renowned scholars, it presents a brief historical discussion of the phenomenon, definitions and characteristics that distinguish bullying from other recurring conflicts in the workplace. It also discusses the role of work organizations regarding bullying. The paper presents the results of a research carried out in bank agencies from July to September 2010, through individual semi-structured interviews conducted with thirty-seven volunteers who occupied different positions in these agencies. It was possible to identify that bullying at work, as a type of violence, is a phenomenon identified by bank workers in their work environment. In general, they associate bullying to management by pressure, which is focused on goals, production and competitiveness. The results encourage the reflection on the necessity to deal with bullying at work as social problem, in a collective perspective, not just as an individual question.
\end{abstract}

Keywords: violence at work; bullying; workers' welfare; banks. 


\section{Introdução}

Humilhações, ameaças, abusos de poder, agressões verbais, sabotagens de instrumentos de trabalho e injúrias compõem o cenário de hostilidade no trabalho, uma violência multiforme, onipresente, que ronda a jornada do trabalhador. Nesse cenário, há uma forma de violência que nem sempre é percebida como tal, mas que também causa sofrimento e faz adoecer: o assédio moral. Trata-se de uma das expressões mais recentes da violência no trabalho, que se caracteriza por atos que minimizam, desvalorizam e agridem o ser humano. Esses atos podem concretizar-se por meio de palavras, gestos, atitudes, falta de atitudes, entre outros. Um ato isolado não pode ser considerado assédio, mas sim sua repetição ou ocorrência sistemática. É uma conduta que atinge a integridade do trabalhador, desgastando-o moral e psicologicamente, podendo levá-lo a somatizações que desestabilizam sua saúde física e psicológica. O assédio moral também pode degradar e prejudicar o clima e o ambiente de trabalho, colocando em risco o emprego e a identidade do trabalhador.

Embora a violência no trabalho seja um problema antigo, visto que maus-tratos, perseguições e ultrajes são praticados desde o início das relações trabalhistas, o assédio moral ainda é um fenômeno pouco conhecido, que só passou a ganhar importância e a constar da pauta das pesquisas acadêmicas por volta da década 80 do século XX, antes mesmo de ser nomeado, no âmbito dos estudos acerca da violência no trabalho, sobretudo na Europa, na esfera dos estudos em Psicologia. Os estudos sobre o assunto só se intensificaram nas duas últimas décadas (SOBOLL, 2008b).

O aumento do número de afastamentos do trabalho causado por problemas psíquicos favoreceu a visibilidade das práticas do assédio moral. Na esfera internacional, constatou-se um crescimento significativo dos problemas de saúde mental e um aumento considerável de pedidos de aposentadoria por incapacidade, assim como de gastos com tratamentos de enfermidades mentais: "uma, em cada dez pessoas, sofre de ansiedade, cansaço e depressão, o que, em alguns casos, leva ao desemprego e à hospitalização" (SCANFONE; TEODÓSIO, 2004, p. 77). Os dados comentados por esses autores, resultados de uma pesquisa realizada em 2000 pela Organização Internacional do Trabalho (OIT), na Alemanha, nos Estados Unidos, na Finlândia, na Polônia e no Reino Unido, revelam a gravidade da situação.

As estatísticas brasileiras fornecidas pelo Instituto Nacional de Seguridade Social (INSS), em 2002, comprovam que os problemas de saúde mental justificam quase $50 \%$ dos afastamentos por mais de 15 dias no trabalho, sendo a depressão o principal motivo (SOBOLL, 2008b). Dados importantes foram fornecidos pela pesquisa desenvolvida por Margarida Barreto, realizada em 2000 com o Sindicato dos Trabalhadores das Indústrias Químicas, Plásticas, Farmacêuticas e Cosméticos de São Paulo envolvendo trabalhadores de 97 empresas. Com um corpus de 2.072 pessoas (1.311 homens e 761 mulheres), essa pesquisa revelou que, do total das pessoas entrevistadas, $42 \%$ haviam vivenciado humilhações, constrangimentos e situações vexatórias repetitivas no local de trabalho, impostas pelo superior hierárquico, forçando-os, frequentemente, a desistir do emprego (BARRETO, 2002). Esses números demonstram tratar-se de um tema atual, novo e de relevância para a pesquisa sobre violência no trabalho e que ainda carece de estudos mais detalhados.

Partindo-se do pressuposto de que o trabalhador bancário é uma das categorias profissionais que mais sofreu com as mudanças decorrentes da reestruturação produtiva (MACIEL et al., 2007), realizou-se um estudo exploratório com o objetivo de identificar como os funcionários de um banco da região Norte concebem o assédio moral.

\section{Métodos}

O trabalho está estruturado em duas grandes partes: a primeira, em que se delineia um breve histórico da discussão sobre o assédio, seus precursores, definições e características que o distinguem de outros conflitos recorrentes em ambientes de trabalho com base em teóricos consagrados na literatura, como Leymann (1996), Dejours (2006), Barreto (2005, 2006), Hirigoyen (2006, 2008), Freitas, Heloani e Barreto (2008), Soboll (2008); e a segunda parte, em que são descritos os elementos da pesquisa empírica (coleta de dados, instrumentos e procedimentos da pesquisa) e apresentadas as interpretações dos dados obtidos.

Trata-se de uma investigação de natureza qualitativa, na qual se adotou a entrevista como método de coleta de dados, procurando-se descrever, analisar e interpretar as percepções dos sujeitos que participaram da pesquisa com base em seus depoimentos e experiências, priorizando-se o significado que dão ao assédio.

A coleta de dados foi realizada durante os meses de julho, agosto e setembro de 2010, consistindo em entrevistas individuais, semiestruturadas, realizadas pela pesquisadora em local escolhido pelos sujeitos da pesquisa - na sede da associação dos 
funcionários do banco, no sindicado dos bancários, no próprio banco ou mesmo em suas residências.

Foram entrevistados 37 voluntários, 17 homens e 20 mulheres, entre 21 e 63 anos de idade. A técnica para a constituição do universo de sujeitos pesquisados foi a de indicações sucessivas entre os participantes (bola de neve), em que para cada entrevistado perguntava-se se poderia indicar algum conhecido para participar da pesquisa. Portanto, não houve uma escolha dos sujeitos a serem entrevistados. Esse número foi suficiente para a identificação de recorrências de informações no que concerne à percepção que os sujeitos têm de assédio. Como o objetivo central da pesquisa foi identificar como os bancários concebem o assédio moral, não foi necessário recorrer a instrumentos para diagnosticar casos de assédio moral. Procurou-se descrever, analisar e interpretar as percepções dos sujeitos que participaram da pesquisa com base em seus depoimentos e experiências. A análise dos dados partiu das entrevistas transcritas que, após a adoção de nomes fictícios para não identificar os entrevistados, foram ordenadas e categorizadas segundo as concepções mais recorrentes apresentadas pelos entrevistados. Em seguida, procedeu-se à interpretação dos depoimentos de forma a ressaltar as concepções encontradas, estabelecendo-se correlações com as questões teóricas destacadas na literatura.

Este estudo foi aprovado pelo Comitê de Ética em Pesquisa do Hospital São Paulo, Universidade Federal de São Paulo (CEP 0397/10).

\section{Resultados e discussão}

\section{Assédio moral: breve histórico, conceituação e carac- terísticas}

A abordagem analítica do assédio moral tem como precursores autores voltados para a discussão do sofrimento no trabalho, como Heinz Leymann (1996). Tomando por base o termo mobbing utilizado por Peter-Paul Heinemann, em 1960, para designar condutas agressivas adotadas por grupos de crianças nas escolas, Leymann constata que esse tipo de ação também ocorria nas empresas suecas, atingindo $3,5 \%$ dos assalariados.

Heinz Leymann (1996), apesar de nunca ter usado o rótulo "assédio moral", inaugurou o campo de estudos sobre esse tipo de violência. Desenvolve e aprofunda seus estudos usando também o termo psicoterror (terror psicológico) para designar o processo de perseguição, violência e exclusão de um trabalhador por outro ou pelo grupo, ou ainda de superiores hierárquicos sobre subordinados e de subordinados sobre superiores hierárquicos no ambiente de trabalho. Em seu livro Mobbing - La persécution au travail, originalmente publicado em 1993, o autor reflete sobre as situações ocorridas no ambiente de trabalho que impõem ao indivíduo danos psíquicos e físicos, tais como confrontos, maus-tratos, desprezo, agressões frequentes. Sem usar a expressão "assédio moral”, acaba por definir a violência no trabalho como um comportamento abusivo que se revela por meio de palavras, atos, gestos, escritos unilaterais de modo a atingir a personalidade, a dignidade, a integridade física e psíquica de uma pessoa, colocando em risco seu emprego ou deteriorando o clima de trabalho (LEYMANN, 1996).

Pouco depois do trabalho seminal de Leymann, Christophe Dejours, na França, reflete sobre a identidade e o sofrimento no trabalho, assim como a respeito da naturalização do sofrimento do outro e a banalização da injustiça social, aprofundando os estudos acerca dos efeitos da organização do trabalho sobre a saúde mental dos trabalhadores (DEJOURS, 2006).

Apesar de não utilizar explicitamente a expressão "assédio moral”, em seu livro Souffrance en France: la banalisation de l'injustice sociale, publicado em 1998, Dejours apresenta uma definição daquilo que ele denomina "males do trabalho" muito próxima do que outros autores entendem por assédio moral. Para ele, os males do trabalho consistem em ameaças, chantagens e insinuações contra os trabalhadores para desestabilizá-los psicologicamente e induzi-los ao erro para, em seguida, usar esse erro como pretexto para a demissão. Quanto à conduta das empresas, Dejours (2006) destaca a perseguição àqueles que não colaboram, que são deixados de lado ou transferidos para um setor execrável, ou ainda colocados diante de condições insuficientes para realizar e cumprir a contento suas tarefas. As ideias de Dejours, embora sem o rótulo "assédio moral", mantêm profundas relações com o tema e certamente contribuíram para fazer avançar as reflexões acerca do assunto.

Marie-France Hirigoyen criou a expressão "assédio moral” para retratar a violência perversa no mundo do trabalho. Foi ela quem apresentou a primeira definição do termo (HIRIGOYEN, 2006):

[...] o assédio moral no trabalho é definido como qualquer conduta abusiva (gesto, palavra, comportamento, atitude...) que atente, por sua repetição ou sistematização, contra a dignidade ou integridade psíquica ou física de uma pessoa, ameaçando seu emprego ou degradando o clima de trabalho. (p. 17)

Para Hirigoyen, é importante distinguir assédio moral - violência que destrói psiquicamente e se repete no tempo - da violência do cotidiano, a que qualquer um está exposto e que procede do mau humor, do nervosismo e da impaciência. O que diferencia essas duas formas de violência é a repetição, a insistência e a sistematicidade. Para ela, assim como para Leymann (1996), um ato isolado não é profun- 
damente grave, o que constitui problema é o efeito cumulativo, que gera nas vítimas sentimentos de rejeição, desprezo e humilhação (HIRIGOYEN, 2006).

Hirigoyen (2006) observa que o ambiente organizacional é marcado por circunstâncias que podem ser confundidas com assédio. Por isso é importante distinguir as práticas de assédio propriamente dito das situações de estresse, conflito, gestão por injúria, agressões pontuais, más condições de trabalho e imposições profissionais.

Segundo Hirigoyen (2006), as empresas estão tornando-se cada vez mais exigentes e duras, cobrando mais e mais de seus trabalhadores. Para isso, recorrem à "gestão por pressão", que acaba conduzindo ao estresse. Entretanto, segundo ela, na gestão por pressão, não existe intencionalidade maldosa, seu objetivo é melhorar o desempenho, e não destruir:

No assédio moral, o alvo é o próprio indivíduo, com um interesse mais ou menos consciente de prejudicá-lo. Não se trata de melhorar a produtividade ou otimizar os resultados, mas de se livrar de uma pessoa porque, de uma maneira ou de outra, ela incomoda. (HIRIGOYEN, 2006, p. 23)

Já a gestão por injúria consiste no comportamento de gestores despreparados que submetem seus funcionários a violências, insultos, pressões e desrespeito. O que diferenciaria esse tipo de gestão do assédio moral é o fato de ser uma violência percebida por todos, enquanto o assédio moral tende a ser uma violência velada. Quanto às agressões pontuais, embora não deixem de ser violência, são atitudes momentâneas, esporádicas; já o assédio é praticado sistemática e repetidamente. No que tange às "más condições de trabalho", o fator que as diferenciaria do assédio moral é a intencionalidade. $\mathrm{O}$ fato de se trabalhar em um espaço sem condições adequadas ou de se ter sobrecarga de trabalho não pode ser considerado assédio moral, a não ser que um único trabalhador seja submetido a essas condições deliberadamente (HIRIGOYEN, 2006).

Em relação às imposições profissionais, é importante, segundo a autora, ter a consciência de que avaliações, críticas construtivas, transferências, mudanças de função e outras atitudes, quando ocorrem de forma respeitosa, sem o propósito de perseguição ou represália, não podem ser consideradas assédio moral. Já metas impossíveis que levam os trabalhadores a um estado de pressão que afeta sua saúde, tornando-se abusivas, enquadram-se na definição de assédio (HIRIGOYEN, 2006).

Assim, concebendo o fenômeno como uma violência que acontece geralmente de modo velado, com intencionalidade maldosa, de modo repetido e sistemático sob a forma de diferentes atitudes hostis que afetam a saúde dos trabalhadores e de- gradam o clima no ambiente de trabalho, Hirigoyen não apenas inaugura a expressão "assédio moral", como também abre caminho para diversas pesquisas sobre o assunto.

No Brasil, Margarida Barreto utiliza e difunde a expressão "assédio moral" após realizar uma pesquisa, entre 1996 e 2000, junto a mais de 2 mil trabalhadores de 97 empresas dos setores químico, farmacêutico e similares da região da Grande São Paulo. Para ela, toda vez que o trabalhador está sujeito, em sua jornada de trabalho, a humilhações e a constrangimentos, impostos, em geral, por superiores, de forma sistemática e prolongada, ele está vivenciando uma situação de assédio moral. Ressalta ainda que as situações de assédio acabam por desestabilizar a relação do trabalhador com o ambiente de trabalho e a organização, podendo levá-lo a renunciar ao emprego (BARRETO, 2005).

Margarida Barreto (2005) situa o assédio moral no âmbito de uma relação de poder, como uma forma de poder coercitivo, que é sustentado pela humilhação, pelo medo e silêncio. Nessa relação, predominam, entre os líderes, atitudes de fuga e, entre os pares, pactos de tolerância e silêncio, evitando-se explicações ou soluções para o problema. A autora recusa as simplificações do assédio segundo as quais o fenômeno resultaria da ação de um indivíduo perverso, e resgata a responsabilidade das empresas. Para ela, as instituições reforçam, fortalecem e produzem perfis assediadores de acordo com seus interesses e objetivos.

Maria Ester de Freitas (2001) procura contextualizar o fenômeno do assédio moral na esfera organizacional e caracterizar essa prática. Em seu artigo, intitulado "Assédio moral e assédio sexual: faces do poder perverso nas organizações", a autora afirma que:

[Em nosso cotidiano], podemos defrontar-nos com si-
tuações que nos minam as forças e que podem arre-
bentar-nos; tais situações constituem verdadeiros as-
sassinatos psíquicos, porém apresentam-se como uma
violência indireta, em relação à qual muitos de nós, sob
o pretexto da tolerância, nos tornamos complacentes,
indiferentes e omissos. No nosso dia-a-dia, não ou-
samos falar de perversidade; no entanto as agressões
reanimam um processo inconsciente de destruição
psicológica constituído de procedimentos hostis, evi-
dentes ou escondido, de um ou vários indivíduos sobre
o outro, na forma de palavras insignificantes, alusões,
sugestões e não ditos, que efetivamente podem deses-
tabilizar alguém ou mesmo destruí-lo, sem que os que o
cercam intervenham. (FREITAS, 2001, p. 9)

Maria Ester de Freitas (2001) também identifica a repetição e a sistematicidade como traços do assédio e reforça que, se as primeiras manifestações de hostilidade não forem combatidas ou denunciadas, diante do silêncio da pessoa face ao abuso de poder, as desqualificações e as agressões reproduzir-se-ão, 
e a pessoa será acuada, inferiorizada, submetida regularmente a manobras hostis e degradantes.

Roberto Heloani (2003, p. 58) discute as especificidades da violência no trabalho, focalizando a prática do assédio moral como "uma forma particular de violência, sutil e perniciosa; uma forma de violência que gera vítimas entre indivíduos, grupos e organizações". A descrição apresentada por Heloani mostra que o assédio moral caracteriza-se por um processo disciplinador em que se procura anular a vontade daquele que, para o agressor, apresenta-se como ameaça.

Do mesmo modo que os autores que o precederam, Heloani (2003) observa que o assédio moral não é um processo explícito, escancarado; ao contrário, muitas vezes é quase imperceptível, por isso ele o qualifica como uma violência invisível, caracterizada pela intencionalidade:

Consiste na constante e deliberada desqualificação da vítima, levando-a a uma posição de fragilidade, com o intuito de neutralizá-la em termos de poder. Trata-se, portanto, de um processo disciplinador, no qual se busca anular a vontade daquele que, para o agressor, talvez se apresente como ameaça. (HELOANI, 2003, p. 59)

Heloani (2003) constrói uma conceituação consensual para o assédio moral incluindo os aspectos já estabelecidos por outros autores, como a repetitividade - os comportamentos hostis devem repetir-se por um longo período; a intencionalidade - as condutas hostis são deliberadamente dirigidas a uma pessoa ou a um grupo com o propósito de o prejudicar e enfraquecer suas possibilidades de ação, obrigando ao desligamento do trabalho; e a circunscrição espacial - as ações de assédio ocorrem no ambiente de trabalho, entre pessoas que pertencem a uma mesma organização. A reflexão de Heloani (2003) também aponta para o assédio moral não como um fenômeno de natureza individual, decorrente das inter-relações pessoais, mas sim como um fenômeno complexo com dimensões sociais, organizacionais e macroeconômicas.

Lis Soboll (2008a) situa o assédio moral no âmbito da violência psicológica, considerando que pode ser mais perigoso do que a violência física, por causar danos, ao mesmo tempo, ao desenvolvimento físico, mental, espiritual, psicológico e social da vítima. Para a autora, esse tipo de violência pode ser encontrado em qualquer ambiente organizacional e ocorre com mais frequência do que a violência física, embora seja mais difícil de ser identificado.

Segundo Soboll (2008a), a violência psicológica tem recebido cada vez mais a atenção de estudiosos e pesquisadores em virtude de sua repercussão no mundo do trabalho. Do mesmo modo, cada vez mais se tem discutido a violência no trabalho em suas diversas manifestações, como ameaças, intimidações, omissões, humilhações, perseguições, assédio organizacional e assédio moral, entre outras.

Soboll (2008b) considera o assédio moral um tipo grave de violência no trabalho. Concordando com os demais autores já apresentados, ela o define como:

[...] um conjunto de comportamentos hostis, repetitivos e prolongados, que, articulados, se configuram como armadilhas. Estas são elaboradas intencionalmente, com a finalidade de minimizar os espaços de ação, pressionando a pessoa de tal maneira que se torna insustentável a sua permanência num projeto, num setor ou na empresa, podendo levar a pedidos de afastamento, transferências ou desligamento, com possíveis repercussões para a saúde e para sua vida, profissional e social. (p. 34-35)

Soboll acredita que a prática do assedio moral é nociva tanto para as relações de trabalho, quanto para o clima organizacional. As demais pessoas do grupo de trabalho passam a viver em constante estado de alerta por temor de ser a próxima vítima. $\mathrm{O}$ assédio moral, segundo ela, teria desse modo um efeito de estratégia de gestão para todo o coletivo, favorecendo a submissão e inibindo questionamentos em virtude do predomínio do medo (SOBOLL, 2008b).

Como se pôde constatar, são diversas as concepções de assédio moral de acordo com os diferentes pesquisadores do tema. Embora possamos identificar inúmeros pontos em comum, muitas características semelhantes, cada pesquisador descreve comportamentos típicos de assédio conforme sua perspectiva de análise e conforme o contexto social no qual está inserido.

\section{O contexto do trabalho bancário}

\section{Por que os bancários?}

Dentre as categorias profissionais que têm sido alvo de mudanças decorrentes da reestruturação produtiva, destaca-se a dos bancários. As mudanças ocorridas nas últimas décadas acabaram por trazer profundas transformações no trabalho e no contexto do trabalho bancário, provocando o aparecimento de queixas de assédio moral e consequências sérias para a saúde de alguns trabalhadores, tais como a depressão e o suicídio (MACIEL et al., 2007). Hoje, a jornada de trabalho do bancário é mais longa, são muitas as metas a serem cumpridas, é grande a pressão pela produção e há um controle estrito sobre o tempo de trabalho dos funcionários.

O bancário vive uma transformação que o coloca frente a frente às novas formas de organização do trabalho e sofre as consequências disto: um maior número de afastamentos do trabalho por LER (Lesões por Esforços Repetitivos), estresse decorrente do trabalho e sofrimento mental [...]. Diante desse 
quadro, pode-se supor que a prevalência do assédio moral no trabalho na categoria bancária seja elevada. (MACIEL et al., 2007, p. 119-120) ${ }^{3}$

Soboll (2008a) fortalece essa argumentação ao afirmar que, no trabalho bancário, existe uma pressão para executar mal seu trabalho, o próprio sistema exerce essa pressão, que se torna evidente na "fabricação de números”, em condutas antiéticas com clientes e com colegas de trabalho, no uso da violência organizacional como estratégia de gerenciamento de equipes.

Maciel et al. (2007), ao considerarem a ocorrência de situações constrangedoras que duraram até seis meses em uma frequência semanal, constataram que 7,97\% dos bancários haviam sido assediados:

[...] uma prevalência igual ou mais baixa do que a encontrada em amostras européias, como por exemplo, as encontradas por Hoel et al. (2001) e Vartia (1996), de aproximadamente 10\%. (MACIEL et al., 2007, p. 125)

Esses autores levam em conta também as diferentes condições de trabalho da categoria bancária no Brasil e na Europa. As condições brasileiras, dadas as limitações socioeconômicas, são piores. Acrescentam ainda:

\begin{abstract}
Einarsen e Skogstad (1996) atentam para a importância de se diferenciar entre comportamentos negativos que são tolerados e comportamentos que não são tolerados, bem como entre situações que podem ser administradas e situações onde as vítimas têm dificuldade para se defender. Um estudo mais aprofundado sobre como os bancários percebem os diferentes tipos de situações constrangedoras pode ser produtivo para uma melhor compreensão do assédio moral na sua relação com os componentes culturais da organização. (MACIEL et al., 2007, p. 125)
\end{abstract}

De acordo com o levantamento realizado pelo INSS em 2002, os trabalhadores da categoria bancária:

[...] respondem por $55 \%$ dos casos de afastamento por Lesão por esforço repetitivo e distúrbio osteomuscular relacionado ao trabalho (LER/DORT), 93\% por ansiedade e 94\% por depressão. Os transtornos mentais são apontados como a segunda causa de afastamento do trabalho na categoria bancária. (SOBOLL, 2008a, p. 154-155)

Pesquisa recentemente realizada pela Confederação Nacional dos Trabalhadores do Ramo Financeiro (Contraf), em 2011, revelou que o assédio moral acomete $66 \%$ dos bancários no Brasil, segundo divulgado pela Folha de São Paulo (BASÍLIO, 2011). Nessa pesquisa, com base na consulta a 27.644 trabalhadores bancários, constatou-se que "as principais queixas são cobrança abusiva, humilhação e falta de reconhecimento", como afirma ao jornal Juvandia Moreira, presidente do Sindicato dos Bancários de São Paulo.
Por um lado, os bancários são suscetíveis a vivenciar situações de assédio por terem sido muito afetados pelas mudanças decorrentes da reestruturação produtiva. Por outro lado, ainda são poucos os dados sobre a ocorrência de assédio moral com essa categoria na região Norte, o que demostra a importância de pesquisas nessa esfera, uma vez que as informações divulgadas com maior frequência mapeiam as práticas de assédio entre os bancários no Brasil de um modo geral.

\section{O entendimento dos bancários}

O assédio é, via de regra, percebido como um movimento descendente e como uma estratégia usada para se alcançar o cumprimento de metas, que se caracteriza por condutas agressivas e causa transtornos psicológicos. Em geral, os sujeitos entrevistados associam, em suas falas, as condutas de assédio à gestão por pressão, identificando como traços mais marcantes desse fenômeno a cobrança, a imposição, e a ameaça para o alcance de resultados.

As respostas às perguntas "Você já ouviu falar de assédio moral?” e "O que você sabe a respeito do assunto?" permitiram-nos identificar suas percepções e as condutas reconhecidas por eles como tipicamente características de assédio. Nas falas abaixo aparece a ideia de que o assédio é uma forma de violência que consiste em atitudes de cobrança para o cumprimento de metas e na imposição por parte de um superior dirigidas a um subordinado, capazes de provocar transtornos psicológicos.

Sobre assédio moral, eu acho que é aquela, não vamos dizer uma cobrança, mas aquela imposição realizada pelo empregador, de forma que chega a ser uma agressão moral, psicológica, para alcançar um resultado determinado pelo próprio empregador, de maneira que essa cobrança, essa manifestação que o empregador causa sobre o empregado, causa algum tipo de transtorno, algum prejuízo de maneira psicológica. Ela não é feita só pelo empregador, mas sim por uma pessoa que possa ser um superior também [...]. (Fábio, 29 anos, 8 anos de banco)

No dia a dia tem mais a questão do atingimento de metas, que é muito acentuada a cobrança. E aí acaba configurando assédio moral aquela perseguição de tem que bater a meta, se você não bater é porque é um incompetente... (Marília, 63 anos, 30 anos de banco)

Sabe o que acontece? Os bancos estabeleceram essa questão de metas, tudo você tem que atingir meta. Meta pra dar lucro, então, essas metas, aí, o cara que te fiscaliza, ele já tem que ter esse perfil [de assediador] pra ele poder conseguir, dentre os comandados dele, atingir a meta da agência [...] fazer o que tem que ser feito, pra satisfazer o leão [a diretoria], senão

\footnotetext{
${ }^{3} \mathrm{Na}$ verdade, essa suposição tem sido confirmada por pesquisas sobre o assédio no meio bancário, como a recentemente realizada pela Confederação Nacional dos Trabalhadores do Ramo Financeiro (Contraf).
} 
ele perde o cargo dele. Ainda tem isso... (Manuela, 53 anos, 33 anos de banco)

Minha percepção é que é muito decorrente da competição entre as empresas por atingimento de metas, então, normalmente, os prepostos da empresa utilizam desse instrumento [o assédio] como forma de coação pra atingir esses objetivos. (Marcus, 56 anos, 34 anos de banco)

Vinte dos 37 sujeitos entrevistados apontam, em suas falas, a sistematicidade ou a intencionalidade maldosa como traços indicadores de uma situação de assédio, conforme descrito por Leymann (1996), Hirigoyen (2006), Freitas (2001), Barreto (2006), Heloani (2003), Soboll (2008a, 2008b). Muitos recorreram a palavras e expressões em um contexto linguístico que evidencia a ideia de que o assédio não existe sem sistematicidade: "uma prática em que tem de haver certa reincidência”, "[o assédio] requer frequência”, "ele pressupõe repetição", "não é só uma vez, são vários acontecimentos", "era uma coisa que era diária”. Da mesma forma, em relação ao critério de intencionalidade maldosa, os sujeitos da pesquisa, em sua maioria, reconhecem tratar-se de uma violência que presume o propósito consciente de praticá-la. Esse entendimento é verbalizado de diferentes maneiras pelos sujeitos: "[o assédio é uma prática em que] outra pessoa tenta te diminuir, te prejudicar", "[o assédio] pressupõe a intencionalidade, é deliberado [...], você quer que a outra pessoa se sinta isolada, afastada, humilhada", "é bem direcionado", "ele age intencionalmente". Os sujeitos têm consciência de que esse tipo de comportamento não é uma reação impulsiva, ocasional, diante de um problema vivenciado no trabalho, eles reconhecem um comportamento voluntário, que surge da vontade do assediador de causar dano a uma determinada pessoa, por isso se reproduz reiteradamente. As falas abaixo ilustram essa percepção:

Eu entendo que é uma prática em que tem que haver certa reincidência, em que há uma relação de trabalho e uma outra pessoa tenta te diminuir, te prejudicar, e você se sente, é constrangido, em situações constrangedoras, mas que requer uma prática, como eu posso dizer, uma frequência, foi o que ficou mais claro pra mim, agora o que é complicado é o como se provar e como ter certeza que realmente isso é um assédio moral? (Lia, 30 anos, 1 ano de banco)

[O assédio moral] Ele pressupõe a repetição, a intencionalidade, é deliberado, né, uma coisa que você quer que aquela pessoa se sinta isolada, afastada, humilhada... Então, é uma coisa que vai quanto mais acontecendo, não é um momento apenas. (Eva, 46 anos, 26 anos de banco)

Já o aspecto velado, insidioso, implícito, apontado por alguns teóricos como um traço do assédio (HELOANI, 2003; HIRIGOYEN, 2006) é pouco identificado nas falas dos sujeitos. Não são raros os su- jeitos que, ao contrário, referem ofensas explícitas e agressões verbais na presença de colegas, ameaças abertas e gritos mesmo.

Teve um problema lá, que nós vivenciamos, que um funcionário foi mandado pra biblioteca, um engenheiro agrônomo, foi o primeiro colocado no concurso do Banco [...], por essa pessoa, porque ela tinha uma certa, uma certa, digamos, eu não sei a palavra exata, mas era bem vista pelo gerente, entendeu? Então, ela era uma pessoa da confiança do gerente e ela conseguiu levar uma situação que aconteceu na sala contra esse funcionário. E ele foi isolado na biblioteca, ele não saiu pra denunciar, ele simplesmente se debruçou nos livros, ele estava numa biblioteca e estudou, passou noutro concurso e hoje tá bem em outro órgão, em outra instituição, entendeu? E tudo isso aconteceu com a mesma pessoa, e nunca ninguém fez nada e não vai fazer [...]. (Iná, 50 anos, 14 anos de banco)

Encontramos também depoimentos que referem o isolamento e a recusa de comunicação como condutas do assédio, ações identificadas por Leymann (1996), Dejours (2006), Hirigoyen (2006), Freitas (2001) em suas descrições. Iná relata um caso de assédio em que um colega foi colocado em um setor isolado, completamente distante de suas possibilidades de trabalho, fora do seu campo de atuação/ formação, como uma estratégia para privar-lhe do apoio social e, desse modo, dificultar uma possível reação. Já o depoimento de Rodrigo conta de sua vivência de assediado: o gerente não lhe dirigia a palavra, ignorava sua presença, a ponto de levá-lo a dizer "eu não existia".

Eu tava me matando por dentro em função de ter que encarar o gerente todos os dias e me sentir ignorado pelo processo, nem um bom dia, nem boa tarde, nem uma dúvida que ele tivesse, ele podia pisar nos calos, lá, mas ele não consultava comigo, eu não existia. (Rodrigo, 40 anos, 8 anos de banco)

Mais frequentes ainda são as falas que identificam a humilhação, o desrespeito, a dominação, a violência, a desestabilização, a perseguição, o adoecimento como traços característicos do assédio discutidos por muitos teóricos, como Leymann (1996), Dejours (2006), Hirigoyen (2006), Freitas (2001), Barreto (2006), Heloani (2003), Soboll (2008a, 2008b).

Hoje o assédio, no meu entendimento, são essas formas que você tem, é violência física, mental, emocional, instrumentos que te levem à tua desestabilização psicológica dentro do ambiente de trabalho e que com certeza vai refletir na tua vida particular. (Jonas, 48 anos, ex-bancário)

Bom, assédio moral é uma, vamos dizer, uma ação, normalmente de um empregador, ou outra pessoa em que promove diminuição, digamos assim, da outra, né? Isso pode acontecer a partir de palavras e atos também, é aquele que humilha, que diminui realmente a pessoa como pessoa. Isso é um assédio moral a meu ver. (Lúcio, 57 anos, 34 anos de banco) 
[Assédio moral] são todas aquelas situações vivenciadas por qualquer pessoa, situações humilhantes, constrangedoras, pela qual a pessoa pode passar em determinado tempo e que de repente começa a causar certos danos naquela pessoa, né? Não é só de chefia pra empregado, pode ser de empregado pra chefia, de colega pra colega... E hoje é muito comum... Aqui tem muitos casos de colegas que se afastam por problemas de chefia mesmo, que pega muito no pé, que humilha, chama de burro, marca, marca mesmo aquele funcionário o tempo todo. (Cris, 41 anos, 10 anos de banco)

O assédio moral é uma prática comum no ambiente de trabalho em que os superiores hierárquicos fazem com que seus subordinados se sintam humilhados, rebaixados, submetidos a uma situação vexatória, humilhante, se sintam mal. (Alice, 28 anos, sindicalista)

No cenário de uma instituição financeira cercado de competitividade, focado em lucros e resultados, com os valores humanos postos em segundo plano, o assédio moral passa a ser utilizado como uma ferramenta para disciplinar as pessoas da organização ou como um modo deliberado de exercer o poder com o propósito de atingir os objetivos do banco, como atestam alguns depoimentos dos sujeitos pesquisados:

Teve um fato que eu presenciei de um colega que tava sendo perseguido, né? O gerente todo dia vinha cobrar dele coisas que ele não tinha como dar conta e, por exemplo, o gerente queria que ele aprovasse a todo custo o cadastro de cliente, e ele não poderia fazer isso porque muitas vezes tinha erros, faltavam documentos, e, como o gerente queria bater metas, eu presenciei brigas, o gerente gritando com ele e tudo mais, desrespeitando o rapaz, falando até em dizer que ia mandar botar ele à disposição [...] (Wilson, 49 anos, 26 anos de banco)

Ela procurou utilizar o poder que o cargo dela dava pra ela e persuadiu outras pessoas de outros órgãos pra realmente me impedir de conseguir aquilo que eu objetivava. E a primeira coisa que ela colocou foi que ela só me liberava pra fazer o curso se colocasse outra pessoa no meu lugar com o meu mesmo nível de qualificação, coisa que era impossível no banco [...]. Ela me agredia muito verbalmente, na frente de todo mundo, toda vez que eu tentava me colocar, e tudo o que eu fazia, todas as minhas, as minhas, é [pausa], os meus trabalhos, sempre que ela me via assim me respondia com uma certa agressão, né? Ela procurava até me induzir ao erro pra tentar me punir de alguma forma [...]. Eu me via preterida de todo o jeito, o meu trabalho não tinha visibilidade, sempre eram as mesmas coisas, era assim, passar fax. Eu fui contratada no banco como economista, né? E era sempre assim, passar fax, mandar fax pra alguma instituição pedindo alguma documentação, né? Aí, esse fax, ela virava de cabeça pra baixo dizendo sempre que estava errado a maneira que eu estava escrevendo, querendo sempre menosprezar o meu conhecimento. (Iná, 50 anos, 14 anos de banco)

Eu vi colegas perdendo a gratificação, que pra mim pode ser uma forma de assédio moral, né? A pessoa perder a sua função porque foi contrário a uma decisão do chefe que achava que não era aquilo, que poderia tomar uma outra decisão, que poderia comprometer até a instituição... Aí, o chefe encara aquilo como um desrespeito, porque ele é uma autoridade... Então, é um desrespeito e acaba prejudicando, transferindo a pessoa sem função nenhuma e a pessoa acaba ficando deprimida. Teve colegas que tiveram que se afastar do trabalho, passaram um bom tempo afastados por problemas depressivos, ocasionados por isso, por afastamento, é ser transferido de uma área porque você entrou em conflito com o chefe [...]. (Sofia, 47 anos, 14 anos de banco)

Buscando sintetizar o conjunto das falas dos entrevistados em relação ao modo como concebem o assédio moral, observa-se que 19 sujeitos o definem como uma forma de coação, pressão, imposição ou ameaça sofrida por um funcionário com o intuito de levá-lo a realizar uma tarefa com a qual não concorda, ou que está além de sua capacidade, ou fora da sua área de atuação, ou ainda em prol de metas e resultados do banco, podendo haver intencionalidade maldosa:

Mas a gente sempre é cobrado pra vender produto [...] sabe, aquela cobrança incessante [...]. Na área que trabalho, tem esse tipo de coisa, que eu acho que é uma forma de assédio, porque, por exemplo, eu sou caixa, não sou vendedora, não fui contratada pelo banco pra vender produto, e eu acho que tudo que foge àquilo que você tem como seu serviço é um assédio, principalmente pela cobrança, né? Sabe, você tem que vender, tem que vender, você é pressionada o tempo todo pra vender aquilo, apesar que a gente nunca conseguiu alcançar esse tipo de meta... Eu acho que esse tipo de assédio as pessoas já acostumaram, já se acostumaram com isso, e é constante isso. (Moema, 59 anos, 31 anos de banco)

Tem gerente que chama o funcionário de burro, de incompetente porque não vendeu o produto, e isso é comum acontecer, esse tipo de ofensa, na frente das outras pessoas inclusive, é uma pressão muito grande, só que as pessoas já incorporam como parte do seu trabalho, como algo comum mesmo. (Dora, 60 anos, 30 anos de banco)

Já 11 dos sujeitos entrevistados consideram o assédio moral um mal que ocorre no ambiente de trabalho que se origina e se fundamenta em relações de autoritarismo, caracterizadas por humilhações, desrespeitos, constrangimentos, insultos, nas quais nem sempre os envolvidos têm consciência de que se trata de uma situação de assédio:

Eu acho que é da cultura do banco, uma cultura ainda centrada numa relação de mando mesmo, eu acho que tem inclusive a ver com a cultura do nosso Estado, de coronéis. Às vezes, eu tenho a nítida sensação que a pessoa não percebe que está assediando, mas acha aquilo natural, gritar, berrar... (Celina, 43 anos, 5 anos de banco)

Vejo um 'banco adoecido' devido às tensões que se instalaram com essas gestões impostas de uns oito anos pra cá ou mais, mas piorou mesmo de uns quatro anos pra cá... Se faço uma crítica dessa aberta, perco o cargo, sem dúvida, sei lá o que me aconte- 
ce... As gestões são intocáveis, não aceitam a crítica. (Tiago, 55 anos, 30 anos de banco)

$\mathrm{E}$ apenas 7 identificam concomitantemente os traços intencionalidade, sistematicidade e adoecimento nas situações de assédio moral, definindo o fenômeno como uma violência que acontece no trabalho de forma intencional, sistemática e que, ao mesmo tempo, gera danos à saúde do trabalhador, conforme descrito por Leymann (1996), Hirigoyen (2008, 2006), Freitas (2001), Barreto (2006), Heloani (2003), Soboll (2008a, 2008b):

\begin{abstract}
Eu digo que o banco é um baú de assédio moral. E o que que é assédio moral? É essa relação que você mantém de humilhação com o outro, de você buscar o trabalho do outro através do mando, da humilhação, do desrespeito, da falta de valorização do trabalho, da ameaça, de uma constante ameaça a sua avaliação de desempenho. Quando uma pessoa adoece aqui no banco, ela entra com o atestado e ela adoece pela sua condição de saúde física e pela sua condição psíquica porque ela já fica deprimida com o que vão pensar... (Celina, 43 anos, 5 anos de banco)
\end{abstract}

Assédio moral, deixa eu ver se consigo captar bem, é quando um funcionário sofre perseguições pelo seu chefe imediato, superior ou até pelos seus próprios colegas ele sofre algum tipo de pressão, e isso é bem direcionado, não é só uma vez, são vários acontecimentos e que levam a crer que essa pessoa está sendo prejudicada ou até perseguida em seu ambiente de trabalho. (Sofia, 47 anos, 14 anos de banco)

Eu acho que essas situações que afetam o empregado, que afetam o emocional do empregado, principalmente quando elas são frequentes, eu acho que é assédio moral, embora o banco considere que não existe assédio moral, eles não aceitam esse termo assédio moral, no máximo dano moral, ofensa, mas não assédio moral. (Bárbara, 56 anos, 32 anos de banco)

Todos os sujeitos da pesquisa consideram o assédio moral algo comum no ambiente bancário. Vinte e seis, em um universo de 37 sujeitos, afirmam explicitamente que consideram o assédio uma forma de coação, pressão, imposição ou ameaça sofrida por um indivíduo com o propósito de levá-lo a realizar uma tarefa com a qual não concorda, ou que está além de sua capacidade, ou fora da sua área de atuação, quase sempre em prol de metas e resultados de um banco cujos objetivos estão enraizados no sistema produtivo, portanto, a serviço de leis do mercado e da razão econômica. Entretanto, nesse universo de 26 sujeitos, 14 consideram que o assédio moral origina-se apenas dessa dinâmica organizacional. Os outros 12, além de relacionarem o assédio moral à forma de gestão do banco voltada para metas e resultados, apontam também a personalidade autoritária ou arbitrária ou até mesmo perversa, daquele que ocupa o papel de gestor, chamando a atenção, em seus depoimentos, para o fato de que nem todos os gestores exercem o assédio moral em sua gestão, embora todos façam parte do mesmo contexto, do mesmo esquema, submetidos às mesmas pressões. Esses 12 sujeitos consideram, portanto, que há também um componente individual ou psicológico que favorece as práticas de assédio moral, entendendo que os dois fatores - a dinâmica organizacional ligada à logica econômica e a personalidade do assediador - entrelaçam-se, criando todas as condições propícias para que se estabeleça um cenário de violência no trabalho.

\section{Considerações finais}

Nesta pesquisa, a partir de estudo exploratório realizado junto a funcionários de um banco da região Norte, no qual foram abordados 37 sujeitos inseridos em diferentes posições dentro da estrutura do banco, buscamos identificar como os bancários concebem o assédio moral. Situada na confluência de várias vozes teóricas, tendo em vista o fenômeno complexo que se propõe a investigar e seguindo principalmente as pistas indicadas pelos sujeitos entrevistados, a análise dos dados mostrou que o assédio moral é reconhecido como uma forma de pressão diretamente relacionada à política de gestão do banco, política esta que está inserida em um contexto socioeconômico em que o capital impõe novas formas de ultrapassar a produção, intensificando o trabalho e atribuindo-lhe um novo sentido. Isso significa que os sujeitos da pesquisa não veem o assédio como um problema alheio à esfera coletiva, organizacional ou socioeconômica, tampouco como uma forma de violência que se reduz a relações de força entre indivíduos de personalidades difíceis.

Embora alguns sujeitos afirmem que o assédio moral pode ocorrer entre colegas de trabalho pertencentes a um mesmo nível hierárquico, e até partir de um subordinado em direção a um superior, quando relatam situações de assédio, sempre mencionam a forma descendente, ou seja, a maioria admite que a violência parte de um gestor ou de um superior hierárquico e atinge um funcionário que se encontra em uma posição hierarquicamente inferior.

Os depoimentos mostram ainda que grande parte dos sujeitos tem consciência de que esse tipo de violência não é uma reação impulsiva e ocasional de um indivíduo diante de um problema pontual vivenciado no trabalho, mas um comportamento sistemático, repetido, em que há, da parte do assediador, o propósito de prejudicar. A maioria refere ofensas, ameaças e agressões verbais explícitas, feitas ostensivamente na presença de colegas, e não agressões veladas, insidiosas, implícitas.

Dentre as condutas características do assédio moral, os sujeitos destacaram a pressão, o isolamento físico e psicológico, a desatenção ou o descuido em relação às necessidades do outro, a humilhação, 
o desrespeito, a dominação, a agressão, a perseguição, a ofensa, enfim, condutas que afetam a existência do indivíduo.

Portanto, no contexto bancário, foco de nossa observação, as falas dos sujeitos denotam que humilhar o outro é um instrumento de domínio e de controle de corpos e mentes a favor da produção, a favor de uma instituição financeira, a favor de metas, resultados e lucro. As pessoas passam a ser descartadas, olhadas como um produto que serve mais ou menos. As próprias empresas passam a gerar forças de autocontrole por meio da formatação de seus funcionários, que têm de aceitar as regras do jogo, e o assédio moral passa a ser um meio a mais de impor a lógica do banco. Essa discussão remete-nos à questão de que, nos bastidores das práticas de assédio, encontram-se fatores complexos que não se limitam apenas à subjetividade de seus protagonistas, mas que dizem respeito a todo um sistema socioeconômico que engendra e determina esse tipo de conflito.

\section{Contribuições de autoria}

Soares, L. R.: contribuição substancial no projeto, no delineamento, no levantamento de dados, na análise e interpretação; elaboração do manuscrito e contribuição importante na revisão crítica; aprovação final da versão a ser publicada. Villela, W. V.: contribuição substancial no projeto e no delineamento; contribuição importante na sua revisão crítica; aprovação final da versão a ser publicada.

\section{Referências}

BARRETO, M. Assédio moral: o risco invisível no mundo do trabalho. Jornal da Rede Feminina de Saúde, n. 25, p. 18-27, jun. 2002. Disponível em: <http://www.redesaude.org.br/Homepage/ JornaldaRede/JR25/Jornal\%20da\%20Rede\%20 n\%BA\%2025.pdf>. Acesso em: 30 nov. 2009.

. Assédio moral: a violência sutil. Análise epidemiológica e psicossocial no trabalho no Brasil. 2005. 188 f. Tese (Doutorado em Psicologia Social)Pontifícia Universidade Católica, São Paulo, 2005.

. Violência, saúde e trabalho: uma jornada de humilhações. São Paulo: EDUC, 2006.

BASILIO, P. Assédio moral atinge 66\% dos bancários no Brasil. Folha de São Paulo, São Paulo, 31 jul. 2011. Disponível em: <http://classificados.folha.uol.com. br/empregos/951999-assedio-moral-atinge-66-dosbancarios-no-brasil.shtml.>. Acesso em: 31 jul. 2011.

DEJOURS, C. A banalização da injustiça social. 7. ed. Rio de Janeiro: FGV, 2006.

FREITAS, M. E. Assédio moral e assédio sexual: faces do poder perverso nas organizações. Revista de Administração de Empresas, São Paulo, v. 41, n. 2, p. 8-19, abr./jun. 2001.

FREITAS, M. E.; HELOANI, J. R.; BARRETO, M. Assédio moral no trabalho. São Paulo: Cengage Learning, 2008.
HELOANI, J. R. Violência invisível. RAE Executivo. São Paulo, v. 2, n. 3, p. 57-61, ago./out. 2003.

HIRIGOYEN, M.-F. Mal-estar no trabalho: redefinindo o assédio moral. 3. ed. Rio de Janeiro: Bertrand Brasil, 2006.

. Assédio moral: a violência perversa no cotidiano. 10. ed. Rio de Janeiro: Bertrand Brasil, 2008.

LEYMANN, H. Mobbing. La persécution au travail. Paris: Éditions du Seuil, 1996.

MACIEL, R. H. et al. Auto relato de situações constrangedoras no trabalho e assédio moral nos bancários: uma fotografia. Psicologia \& Sociedade, Porto Alegre, v. 19, n. 3, p. 117-128, 2007.

SCANFONE, L.; TEODÓSIO, A. S. S. Assédio moral nas organizações: novas roupagens para uma antiga temática? E \& G Economia e Gestão, Belo Horizonte, v. 4 n. 7, p. 71-80, jun. 2004.

SOBOLL, L. Assédio moral/organizacional: uma análise da organização do trabalho. São Paulo: Casa do Psicólogo, 2008a.

. Assédio moral no Brasil: a ampliação conceitual e suas repercussões. In: SOBOLL, L. (Org.). Violência psicológica e assédio moral no trabalho pesquisas brasileiras. São Paulo: Casa do Psicólogo, $2008 \mathrm{~b}$. 